\title{
Synthesis and Characterization of Quaternary Ammonium-based Ionic Liquids Containing an Alkyl Carbonate Group
}

\author{
Dinh Quan Nguyen, ${ }^{+, 4}$ Ji Hee Oh, ${ }^{+,}$Chang Soo Kim, ${ }^{\ddagger}$ Seung Wook Kim,,,+ \\ Honggon Kim, ${ }^{4}$ Hyunjoo Lee, ${ }^{+, *}$ and Hoon Sik Kim ${ }^{\dagger, *}$ \\ "Department of Chemistry, Kynung Hee University, Seoul 130-701, Korea. EE-mail: khs2004@khuac.kr \\ Division of Eniroment and Process Technology, Korea Institute of Science and Technologv, Seoul 136-791, Korea \\ "E-mail: hilee@kistre.kr \\ ${ }^{\$}$ Department of Chemical \& Biological Engineering, Korea University, Seonl 136-701, Korea \\ Received June 7, 2007
}

\begin{abstract}
$\Lambda$ series of quaternary ammonium-based ionic liquids (ILs) containing an alkyl carbonate group on the cation was first prepared and their physical and electrochemical properties including density, viscosity, thermal stability, electrochemical stability, and ionic conductivity were reported. These ILs exhibited wide electrochemical windows of at least $5.0 \mathrm{~V}$ and relatively high conductivities. In contrast to dialkyl-substituted ionic liquids, the ILs with an alkyl carbonate group on the cation showed much smaller drop in conductivities when mixed with a lithium salt, due to the interaction of lithium ions with carbonate groups. Upon interaction with a Li salt, the carbonyl stretching frequency of the carbonate group shifted to a lower frequency whereas the peak associated with $\mathrm{C}-\mathrm{O}$ single bond moved to a higher frequency.
\end{abstract}

Key Words : Ionic liquids, Carbonates, Lithium battery, Electrolyte, Additive

\section{Introduction}

Ionic liquids (ILs) have received considerable interest in various fields of chemistry such as green solvents, catalysts, and separation. ${ }^{1-3}$ ILs have also been considered as promising alternatives to conventional organic carbonates, due to their favorable properties such as wide electrochemical window, high ionic conductivity, non-flammability, and wide operating temperature range. ${ }^{4-7}$

The application of ILs as electrolytes of lithium ion battery, however, has been restricted due to either their low cathodic stability toward lithium or low conductivity arising from the high viscosities. ${ }^{6}$ For this reason, many attempts were made to develop alternative ionic liquids with better performance via structural modification of cations. Ionic liquids based on 2-substituted imidazolium, ${ }^{8}$ tetraalkylammonium,,${ }^{9,10}$ pyrrolidinium, ${ }^{11}$ and piperidinium ${ }^{12}$ cations were shown to exhibit high cathodic stability toward lithium.

In a previous report, we have shown that the electrochemical properties of dialkyl substituted ionic liquids such as C-rate performance can be significantly enhanced by replacing one of the alkyl groups on the cations by a methyl acetate group. ${ }^{13.14}$ Being motivated by this result, we have attempted to introduce a carbonate group on the various types of ILs with a hope that ILs with a carbonate group could have both advantages of organic carbonates and ILs. It is also hoped that the favorable interaction between the carbonate group and a lithium salt could improve various electrochemical properties of the resulting electrolytes.

We report here the synthesis and physical and electrochemical properties of a series of ILs containing a carbonate group as well as the FT-IR spectroscopic investigation of the interaction of a lithium salt with a carbonate group.

\section{Experimental Section}

1-Methylimidazole ( $99 \%$ ), 1,2-dimethylimidazole $(99 \%)$, 1-methylpyrrolidine $(98 \%)$, 1-ethylpiperidine $(98 \%), 4-$ methylmorpholine (98\%), methyl chloroformate $(99 \%)$, and 2-bromoethanol $(95 \%)$ were purchased from Aldrich Ltd. Lithium trifluoromethanesulfonimide (LiTFSI) $(99 \%$ ) was a product from TCI (Japan). Solvents were distilled and stored over Linde type $4 \mathrm{~A}$ molecular sieves. Organic volatile products were analyzed by a GC (Agilent 6890) and a GCMSD (Agilent 6890, 5973MSD) equipped with a HP-5 column ( $30 \mathrm{~m} \times 0.32 \mathrm{~m} \times 0.25 \mu \mathrm{m})$.

'H NMR spectra were taken on a Varian UNITYplus-300. Thermogravimetric analysis (TGA) was conducted using a Mettler TGA 50 in a nitrogen atmosphere at a heating rate of $10^{\circ} \mathrm{C} / \mathrm{min}$ in the temperature range $30-900^{\circ} \mathrm{C}$. The melting temperature of the ionic liquids were determined by means of a TA Instruments Q10 differential scanning calorimeter (DSC) in the range from -90 to $50^{\circ} \mathrm{C}$ at a scan rate of $10^{\circ} \mathrm{C} /$ min under a nitrogen atmosphere.

FT-IR spectra were recorded on a Perkin Elmer Spectrum GX spectrophotometer using a specially designed gas cell to avoid the contact with water and air. ${ }^{15}$ Viscosity was measured using a Brookfield DV-II Pro.

The ionic conductivity data were obtained with a Solatron $1260 \mathrm{~A}$ frequency response analyzer. The electrochemical stabilities of the electrolytes were analyzed by means of a cyclic voltammetry ( $\mathrm{CH}$ Instruments Electrochemical Workstation) at an ambient temperature. A glassy carbon working electrode of $3 \mathrm{~mm}$ diameter was used with a platinium wire as the counter electrode and a silver wire as a quasi reference electrode. The scan rate was set to $10 \mathrm{mV} / \mathrm{s}$.

Synthesis of 2-bromoethyl methyl carbonate (BrEMC). 
Methyl chloroformate $(52 \mathrm{~g}, 550 \mathrm{mmol})$ was added dropwise to a solution of 1-methylimidazole $(41 \mathrm{~g}, 500 \mathrm{mmol})$ in acetone $(200 \mathrm{~mL})$ at $0{ }^{\circ} \mathrm{C}$ and reacted for $2 \mathrm{~h}$. After the completion of the reaction, the white precipitate was collected and dried under a vacuum at room temperature. 2Bromoethanol $(56.2 \mathrm{~g}, 450 \mathrm{mmol})$ in diethyl ether $(200 \mathrm{~mL})$ was then added slowly into the above solid in a $250 \mathrm{~mL}$ round flask and stirred vigorously for $2 \mathrm{~h}$ to give a transparent two-phase liquid mixture. The upper layer mostly consisting of 2-bromoethylmethyl carbonate and diethyl ether was separated from the lower phase of 1-methylimidazole $\mathrm{HCl}$ salt and distilled under a reduced pressure of 4 torr at $60^{\circ} \mathrm{C}$ to give 2-bromoethyl methyl carbonate (transparent liquid, yield: 70\%). 'H NMR $\left(300 \mathrm{MHz}, \mathrm{CDCl}_{3}, 25\right.$ $\left.{ }^{\circ} \mathrm{C}\right)$ for BrEMC: $\delta(\mathrm{ppm})=4.35\left(\mathrm{t}, J=6.0 \mathrm{~Hz}, 2 \mathrm{H}, \mathrm{BrCH}_{2}\right)$, $3.72\left(\mathrm{~s}, 3 \mathrm{H}, \mathrm{CH}_{3}\right), 3.46\left(\mathrm{t}, J=6.0 \mathrm{~Hz}, 2 \mathrm{H}, \mathrm{OCH}_{2}\right)$.

1-[2-(Methoxycarbonyloxy)ethyl]-3-methylimidazolium trifluoromethane sulfonimide [EMCMIm]TFSI (1). BrEMC ( $20.1 \mathrm{~g}, 120 \mathrm{mmol}$ ) was added slowly into a $100 \mathrm{~mL}$ two-neck flask containig 1-methylimidazole $(8.2 \mathrm{~g}, 100$ mmol) in $\mathrm{CH}_{3} \mathrm{CN}(70 \mathrm{~mL})$ over night of $30 \mathrm{~min}$ at room temperature with a vigorous stirring under a nitrogen atmosphere. The flask was then heated to $50^{\circ} \mathrm{C}$ and reacted for over night. After the reaction, the flask was cooled down to room temperature and diethyl ether was added to the reaction mixture to give white precipitates. The solid precipitates was collected, washed with diethyl ether, and dried under vacuum to give 1-[2-(methoxycarbonyloxy)ethyl]-3-methylimidazolium bromide ([EMCMIm]Br) $(24.1 \mathrm{~g}$, yield: $91 \%$ ). The produced [EMCMIm]Br (13.2 $\mathrm{g}, 50 \mathrm{mmole})$ was dissolved in $\mathrm{CH}_{2} \mathrm{Cl}_{2}(50 \mathrm{~mL})$ and reacted with lithium trifluoromethanesulfonimide (LiTFSI) (14.4 g, 50 mmole) for $5 \mathrm{~h}$ under a nitrogen atmosphere. After filtering the precipitated $\mathrm{LiBr}$, the filtrate was washed with water several times to remove dissolved $\mathrm{LiBr}$ and exessive LiTFSI and then dried under vacuum at $80^{\circ} \mathrm{C}$ to give $1-[2-$-(methoxycarbonyloxy)ethyl]-3-methylimidazolium trifluoromethanesulfonimide [EMCMIm]TFSI as a transparent liquid (18 g, $95 \%$ ). Elemental analysis calcd (\%) for $\mathrm{C}_{10} \mathrm{H}_{13} \mathrm{~F}_{6} \mathrm{~N}_{3} \mathrm{O}_{7} \mathrm{~S}_{2}: \mathrm{C}$, $25.8 ; \mathrm{H}, 2.8 ; \mathrm{N}, 9.0$. Found: $\mathrm{C}, 24.9 ; \mathrm{H}, 2.3 ; \mathrm{N}, 8.7$. 'H NMR $\left(300 \mathrm{MHz}\right.$, acetone- $\left.\mathrm{d}_{6}, 25^{\circ} \mathrm{C}\right): \delta(\mathrm{ppm})=9.12(\mathrm{~s}, 1 \mathrm{H}, \mathrm{CH}-$ $\operatorname{Im}), 7.81$ (d, $J=13.5 \mathrm{~Hz}, 3 \mathrm{H}, \mathrm{CH}-\mathrm{Im}), 4.76(\mathrm{t}, J=4.5 \mathrm{~Hz}$, $\left.2 \mathrm{H}, \mathrm{OCH}_{2}\right), 4.63\left(\mathrm{t}, J=4.5 \mathrm{~Hz}, 2 \mathrm{H}, \mathrm{NCH}_{2}\right), 4.13(\mathrm{~s}, 3 \mathrm{H}$, $\left.\mathrm{CH}_{3}\right), 3.78\left(\mathrm{~s}, 3 \mathrm{H}, \mathrm{CH}_{3}\right) .{ }^{13} \mathrm{C}-\mathrm{NMR}\left(75.4 \mathrm{MHz}, \mathrm{CDCl}_{3}, 25\right.$ $\left.{ }^{\circ} \mathrm{C}\right): \delta(\mathrm{ppm})=155.14(\mathrm{OCOO}), 136.52(\mathrm{CH}-\mathrm{Im}), 124.16$ (CH-Im), 199.94 (q, $\left.J=1277 \mathrm{~Hz}, \mathrm{CF}_{3}\right), 123.23$ (CH-Im), $65.53\left(\mathrm{CH}_{2} \mathrm{O}\right), 55.39\left(\mathrm{OCH}_{3}\right), 48.82\left(\mathrm{NCH}_{2}\right), 36.46\left(\mathrm{NCH}_{3}\right)$.

Other types of ILs containg a carbonate group on the cation were prepared similarly to that employed in the synthesis of [EMCMIm]TFSI. All of them were also obtained as transparent viscous liquids.

$N$-[2-(Methoxycarbonyloxy)ethyl]- $N^{\prime}$-methylpyrrolidinium trifluoromethane sulfonimide [EMCMPyr]TFSI (2). Transparent liquid. Elemental analysis calcd $(\%)$ for $\mathrm{C}_{11} \mathrm{H}_{18-}$ $\mathrm{F}_{6} \mathrm{~N}_{2} \mathrm{O}_{7} \mathrm{~S}_{2}: \mathrm{C}, 28.2 ; \mathrm{H}, 3.9 ; \mathrm{N}, 6.0$. Found: $\mathrm{C}, 26.8 ; \mathrm{H}, 3.6 ; \mathrm{N}$, 5.8. ${ }^{1} \mathrm{H}$ NMR $\left(300 \mathrm{MHz}\right.$, acetone- $\left.\mathrm{d}_{6,}, 25^{\circ} \mathrm{C}\right): \delta(\mathrm{ppm})=4.72$ (t, $J=4.5 \mathrm{~Hz}, 2 \mathrm{H}, \mathrm{OCH}_{2}$ ), 3.96 (t, $J=5.1 \mathrm{~Hz}, 2 \mathrm{H}, \mathrm{NCH}_{2}$ ), $3.81\left(\mathrm{~s}, 3 \mathrm{H}, \mathrm{OCH}_{3}\right), 3.78\left(\mathrm{t}, J=3.8 \mathrm{~Hz}, 4 \mathrm{H}, \mathrm{CH}_{2} \mathrm{NCH}_{2}\right), 3.32$ $\left(\mathrm{s}, 3 \mathrm{H}, \mathrm{NCH}_{3}\right), 2.31\left(\mathrm{~m}, 4 \mathrm{H}, \mathrm{C}_{4} \mathrm{H}_{6}\right) .{ }^{13} \mathrm{C}-\mathrm{NMR}(75.4 \mathrm{MHz}$, $\left.\mathrm{CDCl}_{3}, 25^{\circ} \mathrm{C}\right): \delta(\mathrm{ppm})=155.50(\mathrm{OCOO}), 120.85(\mathrm{q}, J=$ $\left.1277 \mathrm{~Hz}, \mathrm{CF}_{3}\right), 66.42\left(\mathrm{CH}_{2} \mathrm{NCH}_{2}\right), 63.16\left(\mathrm{OCH}_{2}\right), 62.47$ $\left(\mathrm{NCH}_{2}\right), 55.47\left(\mathrm{OCH}_{3}\right), 49.13\left(\mathrm{NCH}_{3}\right), 21.97\left(\mathrm{C}_{2} \mathrm{H}_{4}\right)$.

$N$-[2-(Methoxycarbonyloxy)ethyl]- $N^{\prime}$-ethylpiperidinium trifluoromethane sulfonimide [EMCEPip]TFSI (3). Transparent liquid. Elemental analysis calcd $(\%)$ for $\mathrm{C}_{13} \mathrm{H}_{22} \mathrm{~F}_{6} \mathrm{~N}_{2} \mathrm{O}_{7} \mathrm{~S}_{2}: \mathrm{C}, 31.5 ; \mathrm{H}, 4.5 ; \mathrm{N}, 5.6$. Found: $\mathrm{C}, 29.8 ; \mathrm{H}$, $4.2 ; \mathrm{N}, 5.4{ }^{1}{ }^{1} \mathrm{H} \mathrm{NMR}\left(300 \mathrm{MHz}\right.$, acetone-d, $\left.25^{\circ} \mathrm{C}\right): \delta(\mathrm{ppm})$ $=4.70\left(\mathrm{t}, J=4.8 \mathrm{~Hz}, 2 \mathrm{H}, \mathrm{OCH}_{2}\right), 3.82\left(\mathrm{~s}, 3 \mathrm{H}, \mathrm{OCH}_{3}\right), 3.75$ (t, $\left.J=5.1 \mathrm{~Hz}, 2 \mathrm{H}, \mathrm{CH}_{2} \mathrm{~N}\right), 3.67\left(\mathrm{t}, 4 \mathrm{H}, J=5.1 \mathrm{~Hz}, \mathrm{CH}_{2} \mathrm{NCH}_{2}\right.$ ), $2.06\left(\mathrm{~m}, 4 \mathrm{H}, \mathrm{NC}_{4} \mathrm{H}_{6}\right), 1.79\left(\mathrm{~m}, 2 \mathrm{H}, \mathrm{CH}_{2}\right), 1.46(\mathrm{t}, J=7.2 \mathrm{~Hz}$, $\left.3 \mathrm{H}, \mathrm{CH}_{3}\right) .{ }^{13} \mathrm{C}-\mathrm{NMR}\left(300 \mathrm{MHz}, \mathrm{CDCl}_{3}, 25^{\circ} \mathrm{C}\right): \delta(\mathrm{ppm})=$ 155.48 (OCOO), $120.78\left(\mathfrak{q}, J=1277 \mathrm{~Hz}, \mathrm{CF}_{3}\right) 61.06$ $\left(\mathrm{OCH}_{2}\right), 60.23\left(\mathrm{CH}_{2} \mathrm{NCH}_{2}\right), 56.98\left(\mathrm{NCH}_{2}\right), 55.49\left(\mathrm{OCH}_{3}\right)$, $21.38\left(\mathrm{CH}_{2}\right), 20.34\left(\mathrm{CH}_{2}\right), 20.04\left(2 \mathrm{CH}_{2}-\mathrm{Pyr}\right), 7.32\left(\mathrm{CH}_{3}\right)$.

$N$-[2-(Methoxycarbonyloxy)ethyl]- $N^{\prime}$-methylmorpholinium trifluoromethane sulfonimide [EMCMMor]TFSI (4). Transparent liquid. Elemental analysis calcd (\%) for $\mathrm{C}_{11} \mathrm{H}_{18} \mathrm{~F}_{5} \mathrm{~N}_{2} \mathrm{O}_{8} \mathrm{~S}_{2}: \mathrm{C}, 27.3 ; \mathrm{H}, 3.8 ; \mathrm{N}, 5.8$. Found: $\mathrm{C}, 26.7 ; \mathrm{H}$, $3.5 ; \mathrm{N}, 5.3$. 'H NMR (300 MHz, acetone- $\left.\mathrm{d}_{6}, 25^{\circ} \mathrm{C}\right): \delta(\mathrm{ppm})$ $=4.80\left(\mathrm{t}, J=4.5 \mathrm{~Hz}, 2 \mathrm{H}, \mathrm{OCH}_{2}\right), 4.24\left(\mathrm{~m}, 4 \mathrm{H}, \mathrm{CH}_{2} \mathrm{NCH}_{2}\right)$, $4.12\left(\mathrm{~m}, 4 \mathrm{H}, \mathrm{C}_{2} \mathrm{H}_{6}\right), 3.82\left(\mathrm{~s}, 3 \mathrm{H}, \mathrm{OCH}_{3}\right), 3.79(\mathrm{~m}, 2 \mathrm{H}$, $\left.\mathrm{NCH}_{2}\right), 3.56\left(\mathrm{~s}, 2 \mathrm{H}, \mathrm{NCH}_{3}\right) .{ }^{13} \mathrm{C}-\mathrm{NMR}\left(75.4 \mathrm{MHz}, \mathrm{CDCl}_{3}\right.$, $\left.25^{\circ} \mathrm{C}\right): \delta(\mathrm{ppm})=155.37(\mathrm{OCOO}), 120.72(\mathrm{q}, J=1277 \mathrm{~Hz}$, $\left.\mathrm{CF}_{3}\right), 64.17\left(\mathrm{OCH}_{2}\right), 61.39\left(\mathrm{CH}_{2} \mathrm{NCH}_{2}\right), 61.14\left(\mathrm{NCH}_{2}\right), 60.94$ $\left(\mathrm{CH}_{2} \mathrm{OCH}_{2}\right), 55.46\left(\mathrm{OCH}_{3}\right), 48.12\left(\mathrm{NCH}_{3}\right)$.

\section{Results and Discussion}

Carbonate-functionalized ILs were successfully synthesized as dipicted in Scheme 1. First, BrEMC was prepared via two consecutive steps by reacting 1-methylimidazole with methyl chloroformate followed by a hydrolysis reaction with 2-bromoethanol. Small amount of side product $(<5 \%)$, 2-chloroethyl methyl carbonate (CIEMC), was also produced, but the presence of CIEMC did not affect the next step reaction. Imidazolium, pyrrolidinium, piperidinium and morpholinium-based ionic liquids bearing a carbonate group were prepared by reacting BrEMC with 1-methylimidazole, $N$-methylpyrrolidine, $N$-ethylpiperidine or $N$-methylmorpholine followed by anion exchange reaction with $\mathrm{LiN}\left(\mathrm{SO}_{2} \mathrm{CF}_{3}\right)_{2}$ (LiTFSI). Using the hydrophobic properties of resulting ILs with a TFSI anion, the inorganic solid precipitates, $\mathrm{LiBr}$ and excess LiTFSI were removed completely by washing ILs with water.

Some physical properties of the new ionic liquids were measured and the results were summerized in Table 1 and Figure 1-4. Density ranges between 1.44 and $1.66 \mathrm{~g} / \mathrm{cm}^{3}$ and viscosity changes from 274 to $2820 \mathrm{cP}$ at $30^{\circ} \mathrm{C}$, depending on the structure of the cation. Unfortunately, these carbonate-functionalized ILs showed about ten times higher viscosity than dialkyl substituted ILs and morpholinumbased ionic liquid showed the highest viscosity, $2820 \mathrm{cP}$, probably due to the higher intermolecular interaction caused by polar morpholinium ring. Thermal stabilities of these ILs 


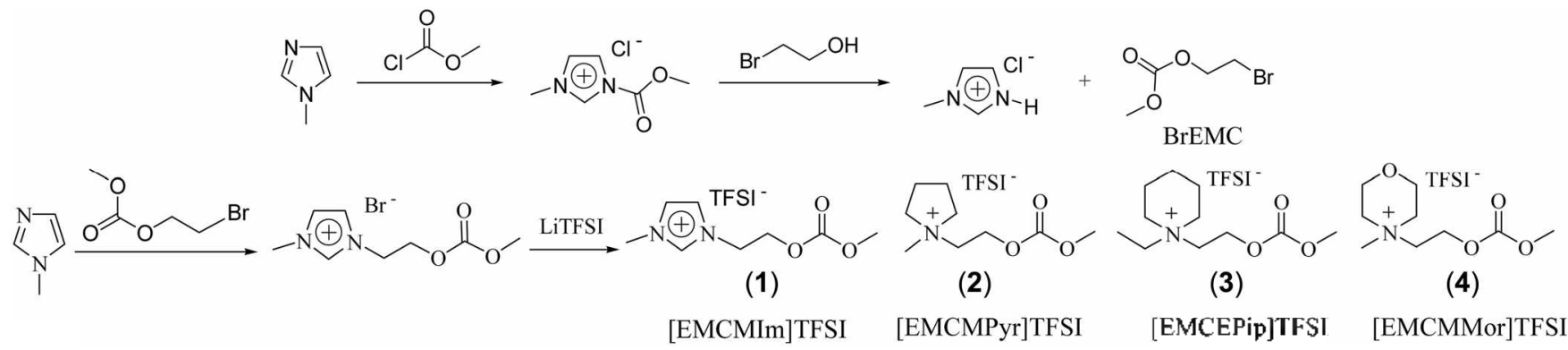

Scheme 1. Synthetic scheme of ILs containing an alkyl carbonate group.

Table 1. Thermal and physical propertics of ILs bearing a carbonate group

\begin{tabular}{|c|c|c|c|c|c|}
\hline Jonic liquid & $\begin{array}{l}\text { Density } \\
\left(25^{\circ} \mathrm{C},\right. \\
\left.\mathrm{g}^{\circ} \mathrm{cm}^{3}\right)\end{array}$ & $\begin{array}{c}\text { Viscosity } \\
\left(30^{\circ} \mathrm{C}\right. \\
\mathrm{cP})\end{array}$ & $\begin{array}{c}\mathrm{T}_{m} \\
\left({ }^{\circ} \mathrm{C}\right)^{4}\end{array}$ & $\begin{array}{l}\mathrm{T}_{\text {decumpl }} \\
\left({ }^{\circ} \mathrm{C}\right)^{b}\end{array}$ & 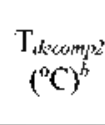 \\
\hline [EMCMIm]TFSI & 1.63 & 326 & -42.5 & 203 & 364 \\
\hline [EMCMPyr]TFSI & 1.61 & 274 & -42.1 & 233 & $\mathrm{n} / \mathrm{d}$ \\
\hline [EMCEPip]TFSI & 1.46 & 618 & -42.2 & 244 & $\mathrm{n} / \mathrm{d}$ \\
\hline [EMCMMor]TFSI & 1.66 & 2820 & -42.0 & 249 & $\mathrm{n} / \mathrm{d}$ \\
\hline
\end{tabular}

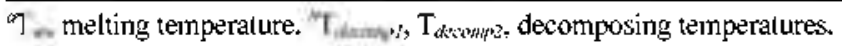

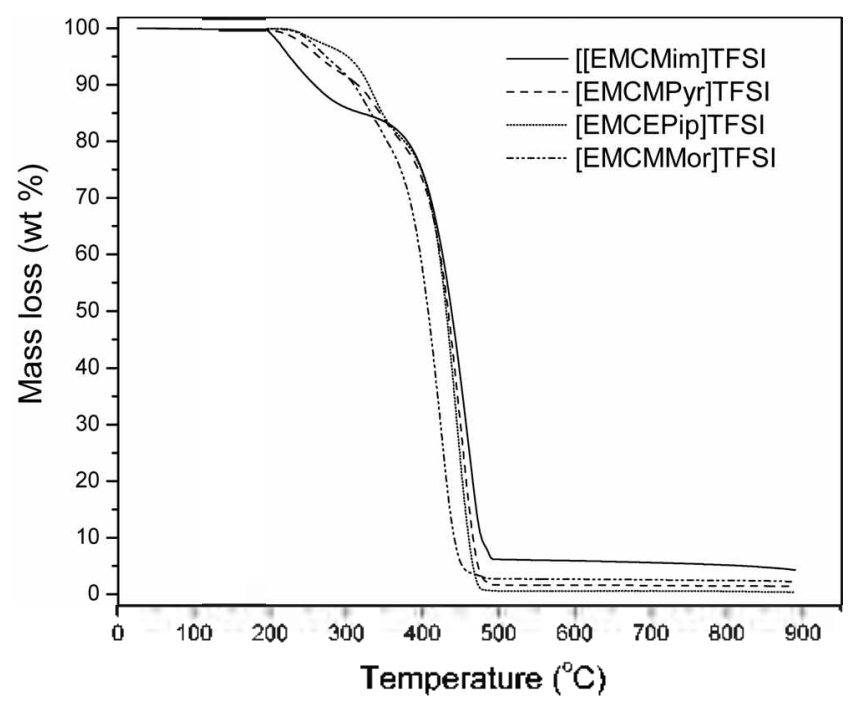

Figure 1. Thermogravimetric analysis (TGA) of various types of ILs containing an alkyl carbonate group on the cations.

were tested under a nitrogen atmosphere between 25 and $900^{\circ} \mathrm{C}$ at a heating rate of $10^{\circ} \mathrm{C} / \mathrm{min}$. As shown in Figure 1 , all the ionic liquids tested exhibited relatively high themal stabilities over $200^{\circ} \mathrm{C}$. Imidazolium-based ILs showed two decomposition temperatures at 203 and $364{ }^{\circ} \mathrm{C}$. The decomposition at lower temperature is likely to be attributed to the decomposition of the carbonate group. Other ILs, pyrrolidinium, piperidinum, and morpholinium salts also showed similar TGA tendencies.

The melting temperatures of these ionic liquids were also determined using DSC. As listed in Table 1, all the ILs tested melt at around $-42{ }^{\circ} \mathrm{C}$, demonstrating their wide liquid temperature ranges. Glass transition temperatures of these ILs were not observed under the experimental condition

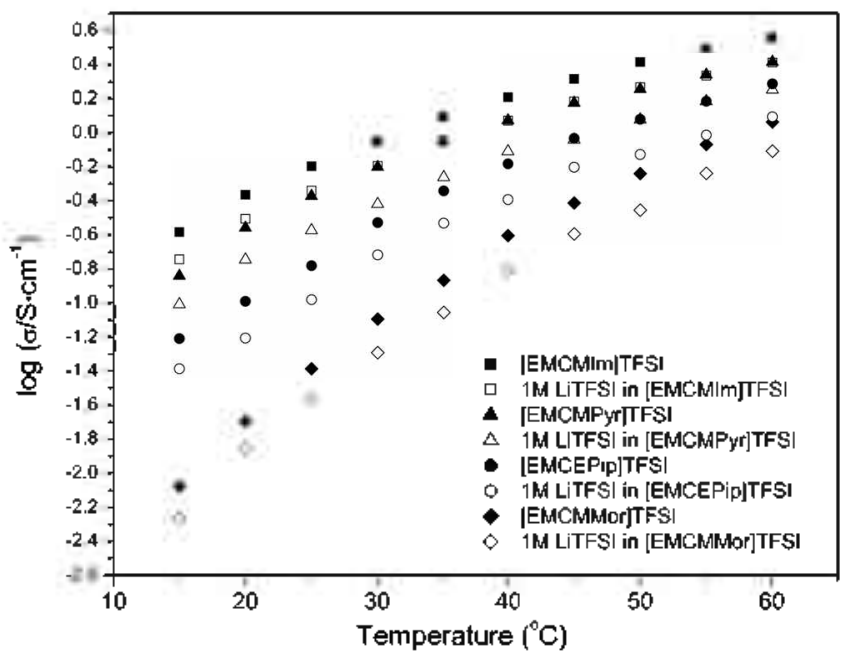

Figure 2. Ionic conductivitics of pure ILs and their mixtures with $1 \mathrm{M}$ LiTFSI as a finction of temperature.

(from $-90^{\circ} \mathrm{C}$ to $100^{\circ} \mathrm{C}$ ).

The ionic conductivities are presented in Figure 2 as a function of temperature. The conductivities of these ILs increased with increasing temperature because of the decrease in viscosity at higher temperatures. The conductivity of an ionic liquid is known to decrease significantly upon mixing with a lithium salt. Especially, the conductivity of a dialkyl substituted ionic liquids such as I-ethyl-3-methylimidazolium trifluoromethanesulfonimide ([EMIm]TFSI) is reduced about $70 \%$ with the addition of $\mathrm{LiPF}_{6 .}{ }^{16}$ Previously, we reported that ILs with an methyl acetate group showed less conductivity decrease (about $30-40 \%$ ) when mixed with $\mathrm{LiPF}_{6 .}{ }^{13}$ Likewise, as shown in Figure 2, ILs with a carbonate functional group exhibited similar phenomenon. The lower conductivity decrease is believed to come from the increased dissociation of LiTFSI salt through an additional interaction of $\mathrm{Li}^{\prime}$ with a carbonyl group in carbonatecontaining ILs. The presence of a functional group in ILs capable of interacting with a lithium salt seems to be indispensable for use as an electrolyte solvent. Without such a functional group, there will be a competition in ion transport between the cations of ILs and $\mathrm{Li}^{\prime}$ ions, which builds a transport barrier resulting in a significant drop in C-rate perfomances of lithium ion batteries. ${ }^{17}$ However, ILs with a carbonyl-containing functional group on the cation will move to the anode along with $\mathrm{Li}^{+}$ions during the charging 


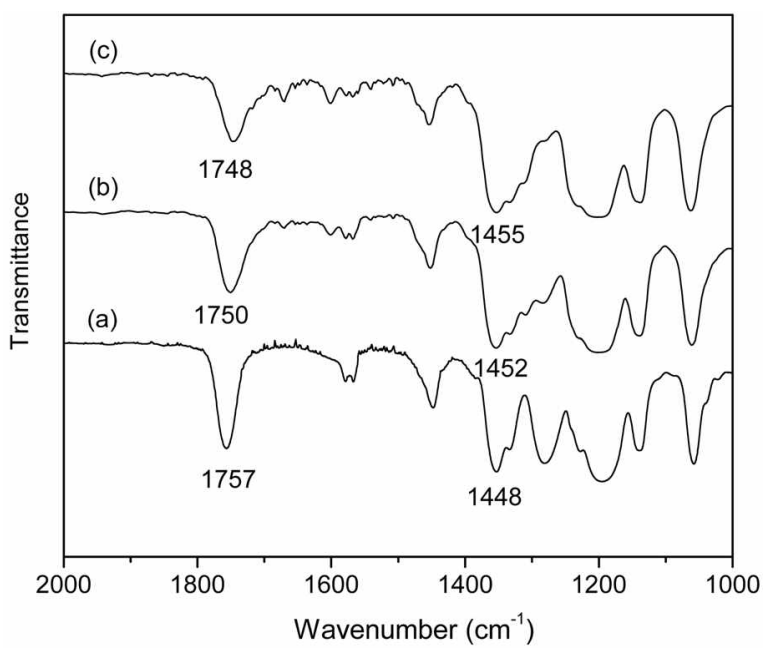

Figure 3. FT-IR spectra showing the interaction of the carbonatecontaining ionic liquids with LiTFSI: (a) [EMCMIı]TTFSI, (b) [EMCMIm]TFSI:LiTFSI = I: 1 , (c) [EMCMIm]TFSI:LiTFSI $=1: 2$.

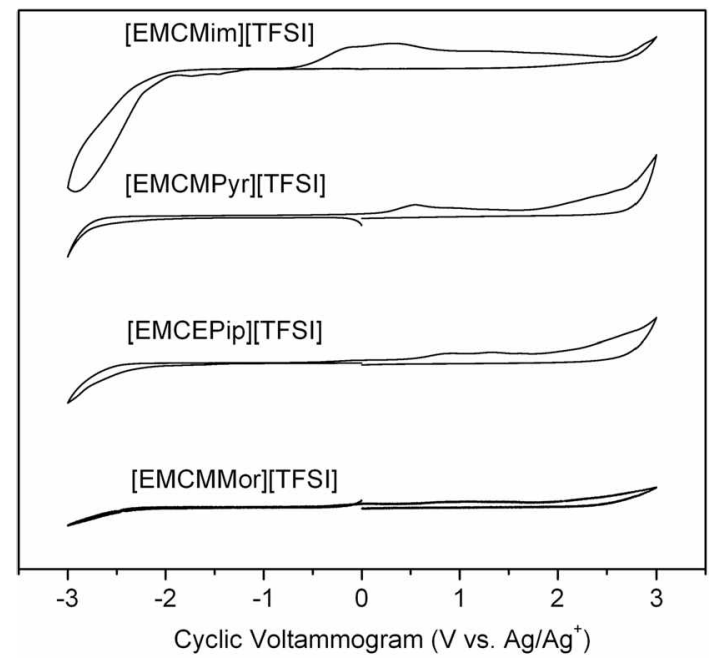

Figure 4. Cyclic voltammogram of ILs containing an alkyl carbonate group on the cations.

process, thereby preventing the build-up of the transport barrier and consequently facilitating the lithium ion transport.

The interaction of a carbonate group with LiTFSI is clearly demonstrated by an FT-IR experiment. As shown in Figure 3, the peak associated with the carbonyl group of [EMCMIm]TFSI shifted to a lower frequency from 1757 to $1748 \mathrm{~cm}^{-1}$ when two equivalents of LiTFSI was added. Whereas, the stretching frequency assigned to the $\mathrm{C}-\mathrm{O}$ single bond moved to a higher frequency to 1455 from 1448

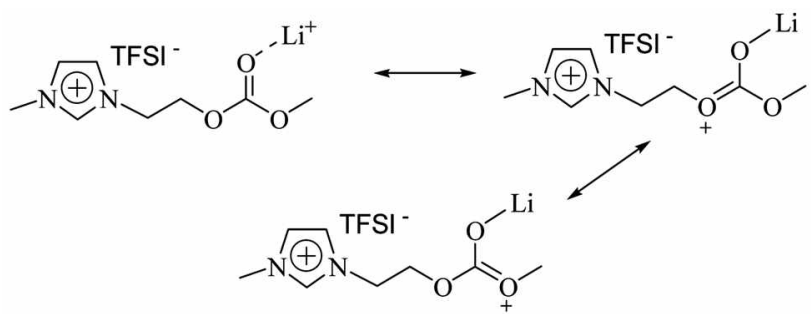

$\mathrm{cm}^{-1}$, possibly due to a resonance between the carbonyl group and $\mathrm{C}-\mathrm{O}$ single bond as depicted below. ${ }^{13,17,18}$

The electrochemical stabilities of ILs bearing a carbonate group were also analyzed by using a cyclic voltammetry (CV) at an ambient temperature. Figure 4 displays the cyclic voltammograms of four different types of ILs containing a methyl ethyl carbonate group. Imidazolium-based IL with an acidic hydrogen on $\mathrm{C}-2$ carbon of the imidazolium ring exhibited low cathodic stability, whereas other ILs showed wide electrochemical windows of at least $5.0 \mathrm{~V}$, indicating these ILs are stable enough to be considered as potential electrolytes or electrolyte additives for lithium batteries.

\section{Conclusions}

ILs bearing an alkyl carbonate group on the cation showed relatively high thermal stability over $200^{\circ} \mathrm{C}$ and wide electrochemical windows about $5 \mathrm{~V}$. The conductivities of carbonate-fuctionalized ILs were found to decrease to a much smaller extent than those of dialkyl substituted ILs when combined with a lithium salt. Such an improvement in physical and electrochemical properties of these ILs can be attributed to the favorable interaction of a lithium salt with a carbonate group, which was confirmed by an FT-IR study. It is expected that these ILs may find some applications as additives or altematives to the conventional carbonate-based electrolytes currently used in the secondary batteries.

\section{References}

1. Rogers, R. D.; Seddon, K. R. Ionic Liguids IIIB: Fundamentals, Progress, Challenges, and Oppontumities; ACS: Washington, DC, 2005.

2. Xu, K, Chem, Rev, 2004, 104, 4303.

3. Joraqur, Y. R.; Chi, D. Y. Bull. Korean Chem. Soc. 2006, 27, 345.

4. Galinski, M.; Lewandowski, A.; Stepniak, I. Electrochini Acta 2006, $51,5567$.

5. Lee, J. S.; Bae, J. Y.; Lee, H. J.; Nguyen, N. D.; Kim, H. S.; Kim, H. G.J. Ind. Eng. Chem. 2004, Jo, 1086.

6. Egashira, M.; Okada, S.; Yamaki, J.; Dri, D. A.; Bonadies, F.; Scrosati, B. J. Power Source 2004, 138, 240.

7. Seki, S.; Ohno, Y.; Kobayashi, Y; Miyashiro, H.; Usami, A.; Mita, Y.; Tokuda, H.; Watanabe, M.; Hayamizu, K.; Tsuzuki, S.; Hatlori, M.; Terada, N. J. Electrochem. Soc. 2007, 154, Al73.

8. Koch, V. R.; Nanjundiah, C.; Appetecchi, G. B.; Scrosati, B. J. Electrochem. Soc. $1995,142,116$.

9. Sun, J.; Forsyth, M.; MacFarlane, D. R. J. Phys. Chen. B 1998, 102,8858 .

10. Matsumoto, M.; Yanagida, M.; Tanimoto, K.; Nomura, M.; Kitagawa, Y; Miyazaki, Y. Chem. Lett. 2000, 922.

11. MacFarlane, D. R.; Meakin, P.; Sun, J.; Amini, N.; Forsylh, M. J. Phys, Chem, B 1999, 103, 4164.

12. Sakaebe, H.; Matzumoto, H. Electrochen. Conmun. 2003, $5,594$.

13. Lee, J. S.; Nguyen, D. Q.; Hwang, J. M.; Bae, J. Y.; Kim, H.; Cho, B. W.; Kim, H. S.; Lee, H. Electrochen. Commun. 2006, 8, 460.

14. Nguyen, D. Q.; Hwang, J.; Lee, J. S.; Kim, H.; Lee, H.; Cheong, M.; Lee, B.; Kim, H. S. Electrochem. Comm. 2007, 9, 109.

15. Haver, J.; Wojciechowska, M. J. Catal 1998, 110, 23.

16. Garcia, B.; Lavallee, S.; Perron, G.; Michot, C.; Armand, M. Electrochim. Acta 2004, 49, 4583 .

17. Lee, S. Y.; Yong, H. H.; Lee, Y. J.; Kim, S. K.; Ahn, S. J. Phys. Chem, B 2005, 109, 13663 .

18. Ryu, J. H.; Lee, H.; Kim, Y. J.; Kang, Y. S.; Kim, H. S. Chem, Eut: J. $2001,7,1525$. 